The Berlin meeting will need to finalize many other decisions as well. One of the most important of these relates to the financial arrangements for the treaty. The COP must finalize guidelines on how developed countries should assist developing countries in implementing the Convention. Because so many decisions must be made at the COP's first session, two more intergovernmental meetings will be held to prepare the way. The first will take place during 22 August-2 September 1994 in Geneva, while the second is scheduled for early 1995 in New York.

MiCHAEL WILLIAMS

UNEP/WMO Information Unit on Climate Change

Geneva Executive Centre

CP 356

CH-1219 Châtelaine

Geneva, Switzerland.

\title{
The Earth Council and Its Tasks for the Future
}

\section{Introduction}

Why are the problems of Environment and Development $(\mathrm{E} / \mathrm{D})$ currently in the doldrums? At the Rio Conference in June 1992, Governments world-wide united to agree on international approaches to the solution of these problems. Why has this optimism been largely replaced by widespread political anxiety in a world now increasingly divided by selfishly national short-term responses to the interrelated problems of poverty, deprivation and illhealth, international trade, and debt, recession, local conflicts, and tribalism? Yet many of these were the very issues that concerned the 187 states which signed the Earth Charter, Agenda 21, and the other agreements, at Rio.

Did they really mean it at the time or are E/D issues turning out to be a ' $\mathrm{cul}$-de-sac' in our thinking, in the manner that so much post-World-War II idealism did when the going got hard? Or are we witnessing the faltering of governments disorientated by the political limbo which has followed the end of the Cold War? Or perhaps we need completely new institutional mechanisms of governance to cope with these problems?

The year 1994 will be a good one for taking stock. Where have our perceptions of $E / D$ come from, and have they really changed human society's view of how it will survive and develop on the Planet Earth? In terms of responses, has anything really been acted on and what has been accomplished? Maybe we are on the wrong track altogether; but in any case, what kind of institutions do we need to help us forward? The Earth Council is clearly one of them; but what will its Programme be like? Who are its supporters and its customers, and do they have the power to effect change and achieve real progress in the right direction?

\section{Earth Council's Establishment}

Founded in September 1992 as a direct result of the 'Earth Summit' held in Rio de Janeiro, Brazil, in June 1992, the Earth Council is a non-governmental organization of important potential.

The 'Earth Summit' produced agreement on basic principles incorporated in the Rio Declaration, and a comprehensive and far-ranging programme of action, Agenda 21 , which is designed to launch the world community onto a new pathway towards a more secure, sustainable, and equitable, future in environmental, economic, and social, terms. But the ultimate impact of these agreements - and the international environmental treaties - will depend on effective arrangements for public monitoring, reviewing, and facilitating, the follow-up and implementation of these decisions.
The unprecedented level of involvement in the 'Earth Summit' of those outside government was the key to its political significance, and the Earth Council has been established to maintain this global effort and broaden the opportunities for an expanded role of independent organizations - particularly those of a 'grassroots' nature - to ensure transparency, accountability, and real public participation.

The Earth Council consists of twenty-one members who are broadly representative of the principal regions of the world and the various sectors of the civil society, each appointed in his or her personal capacity. It will seek to give voices to concerned people from around the world especially those who are not sufficiently heard or heeded in policy and decision-making processes. It will attempt to facilitate redress of grievances and equitable resolution of disputes through a global ombudsman function, investigating and reporting on critical environment and development issues that affect people or violate the rights stemming from the Rio agreements.

\section{Objectives of the Earth Council}

- To facilitate and support peoples' initiatives on behalf of the Earth, particularly in implementation of the governmental and nongovernmental results of the 'Earth Summit';

- To help to ensure that the experience, the concerns, and the interests, of people 'at the grassroots' are brought to bear at all levels of policy- and decision-making;

- To promote greater-than-current interaction and communication between scientists, other experts, and native peoples, on important environment and development issues;

- To promote public awareness in respect of environment and development issues, and to help to ensure that public dialogue on these issues is illuminated by the objective knowledge and opinions of scientists and other experts; and

- To monitor, complement, and support, the work and mission of the United Nations Commission on Sustainable Development.

\author{
GORDON GOODMAN, Chairman \\ International Scientific Committee \\ International Academy of the Environment \\ Chemin de Conches 4 \\ 1231 Conches \\ Geneva, Switzerland; \\ formerly Founding Executive Director, \\ Stockholm Environment Institute.
}

